OPEN ACCESS

Edited by:

Vlada B. Urlacher,

University of Düsseldorf, Germany

Reviewed by:

Roland Wohlgemuth,

Sigma-Aldrich, Switzerland

Kohsuke Honda,

Osaka University, Japan

${ }^{*}$ Correspondence:

Thomas Brück

brueck@tum.de

Specialty section:

This article was submitted to

Process and Industrial Biotechnology,

a section of the journal

Frontiers in Bioengineering and

Biotechnology

Received: 19 April 2016

Accepted: 12 September 2016

Published: 17 October 2016

Citation:

Reiße S, Haack M, Garbe D, Sommer B, Steffler F, Carsten J, Bohnen F, Sieber $V$ and Brück $T$ (2016) In Vitro Bioconversion of Pyruvate to n-Butanol with Minimized Cofactor Utilization.

Front. Bioeng. Biotechnol. 4:74. doi: 10.3389/fbioe.2016.00074

\section{In Vitro Bioconversion of Pyruvate to $n$-Butanol with Minimized Cofactor Utilization}

\author{
Steven Reiße, ${ }^{1,2}$, Martina Haack', Daniel Garbe ${ }^{1}$, Bettina Sommer ${ }^{1}$, Fabian Steffler ${ }^{3}$, \\ Jörg Carsten ${ }^{3}$, Frank Bohnen ${ }^{2}$, Volker Sieber ${ }^{3}$ and Thomas Brück ${ }^{1,2 *}$ \\ ${ }^{1}$ Department of Chemistry, Technical University of Munich, Garching, Germany, ${ }^{2} B \& B$ Sustainable Innovations GmbH, \\ Köln, Germany, ${ }^{3}$ Straubing Center of Science, Technical University of Munich, Straubing, Germany
}

Due to enhanced energy content and reduced hygroscopicity compared with ethanol, $n$-butanol is flagged as the next generation biofuel and platform chemical. In addition to conventional cellular systems, $n$-butanol bioproduction by enzyme cascades is gaining momentum due to simplified process control. In contrast to other bio-based alcohols like ethanol and isobutanol, cell-free $n$-butanol biosynthesis from the central metabolic intermediate pyruvate involves cofactors $[\mathrm{NAD}(\mathrm{P}) \mathrm{H}, \mathrm{COA}]$ and acetyl-CoA-dependent intermediates, which complicates redox and energy balancing of the reaction system. We have devised a biochemical process for cell-free $n$-butanol production that only involves three enzyme activities, thereby eliminating the need for acetyl-CoA. Instead, the process utilizes only NADH as the sole redox mediator. Central to this new process is the amino acid catalyzed enamine-aldol condensation, which transforms acetaldehyde directly into crotonaldehyde. Subsequently, crotonaldehyde is reduced to $n$-butanol applying a 2-enoate reductase and an alcohol dehydrogenase, respectively. In essence, we achieved conversion of the platform intermediate pyruvate to $n$-butanol utilizing a biocatalytic cascade comprising only three enzyme activities and $\mathrm{NADH}$ as reducing equivalent. With reference to previously reported cell-free $n$-butanol reaction cascades, we have eliminated five enzyme activities and the requirement of CoA as cofactor. Our proof-of-concept demonstrates that $n$-butanol was synthesized at neutral $\mathrm{pH}$ and $50^{\circ} \mathrm{C}$. This integrated reaction concept allowed GC detection of all reaction intermediates and $n$-butanol production of $148 \mathrm{mg} \mathrm{L}^{-1}(2 \mathrm{mM})$, which compares well with other cell-free $n$-butanol production processes.

Keywords: butanol, cell-free, enzyme cascade, biocatalysis, chemoenzymatic, synthetic biotechnology

\section{INTRODUCTION}

$n$-Butanol is a primary 4-carbon alcohol, which is flagged as the next generation biofuel and platform chemical due to its enhanced energy content and reduced hygroscopicity compared with ethanol (Li et al., 2010). $n$-Butanol is of interest as a platform chemical in the chemical, textile, polymer, and biofuel industry (Dürre, 2007).

Conventionally, biotechnological $n$-butanol production is based on the anaerobic ABE fermentation process, which utilizes solventogenic Clostridia strains, such as Clostridium acetobutylicum (Lin and Blaschek, 1983; Vollherbst-Schneck et al., 1984; Dusseaux et al., 2013). However, this 
process involves formation of several undesired by-products (i.e., butyrate) (Lee et al., 2008).

In contrast to cell-based production systems, the recent application of artificial, solvent tolerant enzyme cascades provides opportunities for targeted in vitro biobutanol production that allow operation at higher process temperatures. Exemplary, we previously established a modular, in vitro enzyme cascade that allows the flexible conversion of glucose to either ethanol or isobutanol at $50^{\circ} \mathrm{C}$, respectively (Guterl et al., 2012). This enzyme system is based on an artificial glycolytic reaction cascade that utilizes pyruvate as the central intermediate.

In contrast to the in vitro ethanol and isobutanol production system, the design of an $n$-butanol-specific enzyme cascade is more complex and involves several bottlenecks, multiple coenzyme A (CoA)-dependent intermediates and unstable cofactors. The natural clostridial $n$-butanol biosynthesis from glucose comprises 16 enzyme activities, $5 \mathrm{CoA}$-dependent intermediates, 3 cofactors, and several ATP-dependent conversion steps (Inui et al., 2008; Bar-Even et al., 2012; Krutsakorn et al., 2013). At present, an in vitro enzyme cascade for $n$-butanol production from glucose has been described, which in analogy to the cellbased system involves 16 different enzyme activities for glycolysis and an artificial solventogenesis utilizing thermostable enzyme variants (Krutsakorn et al., 2013). Notably, the reaction cascade primarily focused on converting pyruvate to $n$-butanol utilizing seven enzyme activities, $\mathrm{CoA}$ and $\mathrm{NADH}$ as cofactors. In this approach, unbalanced concentrations of CoA-dependent intermediates and generated $\mathrm{NAD}^{+}$inhibit crucial enzyme activities, such as a crotonase similar 3-hydroxypropionyl-CoA dehydratase, thiolase, and $\beta$-hydroxybutyryl-CoA dehydrogenase, thereby limiting product yield (Engel et al., 1996; Sommer et al., 2013a; Reisse et al., 2014). In order to sustain in vitro $n$-butanol biosynthesis in the presence of $\mathrm{CoA}$ and $\mathrm{NAD}^{+}$, therefore, required a time-dependent feeding of metabolic intermediates to overcome enzyme-specific feedback inhibition and temperature-dependent cofactor instability (Krutsakorn et al., 2013). In general, managing the cofactor balance and adjusting a linear production rate is very difficult considering that complete inhibition of a single enzyme activity would arrest the entire process. Furthermore, ATP is unstable under extended process times and at elevated temperatures. In addition, controlling the stoichiometry of various CoA-dependent intermediates requires constant feeding during the reaction, which increases process complexity and cost.

In this study, we have focused on establishing an in vitro $n$-butanol production process from pyruvate at elevated temperatures. This cell-free process is minimized with respect to employed enzyme activities. In comparison to previous studies, we achieved to entirely eliminate all ATP and CoA-dependent reactions using $\mathrm{NADH}$ as the sole redox shuttle. Our study has focused on conversion of pyruvate to $n$-butanol, as there are now several efficient cell-based (Xu et al., 2008) and in vitro routes (Gao et al., 2009; Guterl et al., 2012) for the production of this platform metabolite available. We have chosen a reaction temperature of $50^{\circ} \mathrm{C}$ to be compatible with our previous study describing the cell-free conversion of glucose to pyruvate (Guterl et al., 2012).

The realization of our in vitro biocatalytic reaction cascade predominantly relies on the substitution of CoA-dependent reaction steps by an organocatalyst, such as an amino acid or diamine, which facilitates the direct conversion of acetaldehyde to crotonaldehyde by an enamine-aldol condensation (List, 2002). The implementation of this enamine condensation now enables the bypass of the native $n$-butanol pathway enzymes, such as CoA-acetylating aldehyde dehydrogenase, thiolase, hydroxybutyryl-CoA dehydrogenase, crotonase, and butyrylCoA dehydrogenase. This approach provides direct access to an alternative $n$-butanol cascade, which we postulated previously (Sommer et al., 2013b). The resulting in vitro biocatalytic reaction cascade is the first report of an artificially designed thermotolerant and highly condensed $n$-butanol biosynthesis route (Figure 1).

\section{glycolytic reaction cascade}

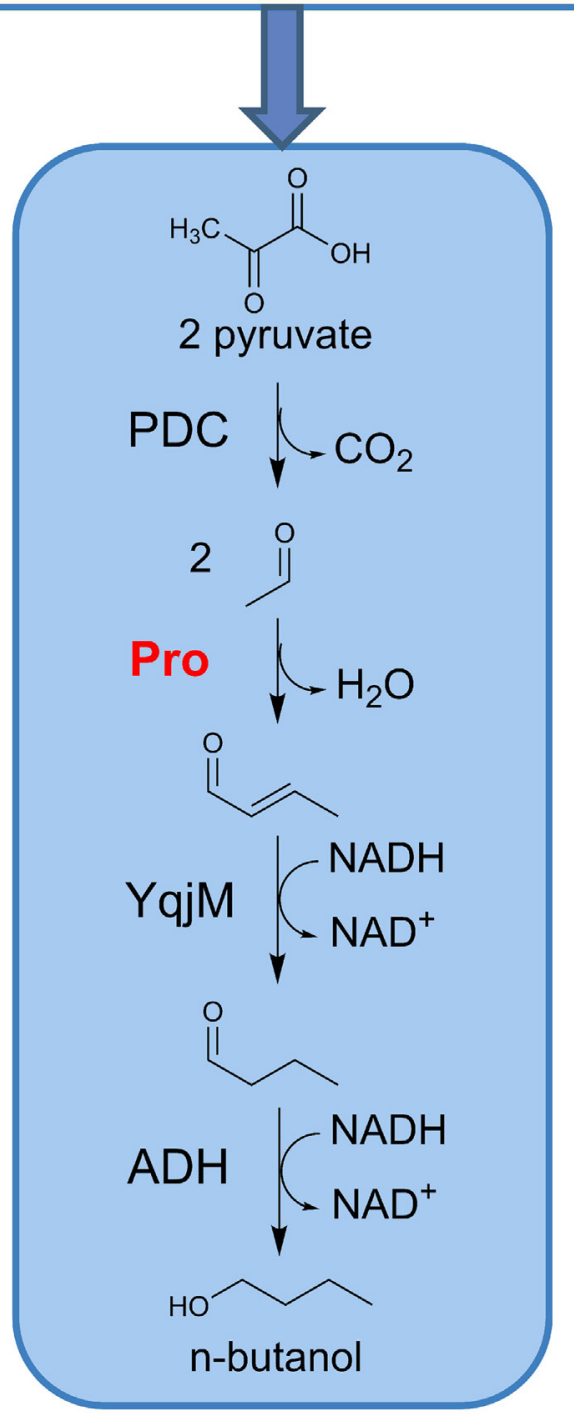

FIGURE 1 | Schematic illustration of the $\boldsymbol{n}$-butanol reaction cascade via the enamine-aldol condensation. PDC, pyruvate decarboxylase; Pro, proline; YqjM, 2-enoate reductase; ADH, alcohol dehydrogenase. 
The primary conversion involves the pyruvate decarboxylase (PDC) to acetaldehyde, which in turn serves as a substrate for the biochemically catalyzed enamine-aldol condensation, utilizing amino acids (i.e., proline) or natural diamines as a catalyst (Figure 2).

In this respect, proline is unique due to its pyrrolidine moiety, which translates to a pronounced nucleophilic reactivity. While the pyrrolidine moiety readily forms iminium ions and enamines (List, 2002), amino acids, such as arginine or tryptophan, featuring a secondary amine moiety can serve as suitable catalysts. Moreover, natural polyamines, such as spermidine or putrescine, show the desired catalytic capacity albeit at lower reactivity compared with the former (Theruvathu et al., 2005).

In a subsequent two-step reaction, the resulting crotonaldehyde is converted to butyraldehyde and finally to $n$-butanol by action of a 2-enoate reductase (YqjM) and an alcohol dehydrogenase (ADH) (Sommer et al., 2013b).

Consequently, our designed biocatalytic $n$-butanol production cascade is consolidated to use only three enzyme activities, an amino acid with secondary amine functionality and $\mathrm{NADH}$ as reducing equivalent. With reference to previously reported in vitro $n$-butanol reaction cascades, we have eliminated five enzyme activities, the requirement of ATP and CoA as a cofactor as well as five CoA-dependent intermediates.

\section{MATERIALS AND METHODS}

\section{Chemicals}

All chemicals were purchased in analytical grade from SigmaAldrich (Munich, Germany) and Carl Roth (Karlsruhe, Germany).

\section{Enzyme Selection}

Pyruvate decarboxylase (Zymomonas mobilis) and YqjM (Bacillus subtilis) were selected due to their established catalytic performance at the desired reaction conditions $\left(50^{\circ} \mathrm{C}\right.$, neutral $\left.\mathrm{pH}\right)$. Moreover, both enzyme systems have previously been used in our cell-free solvent production cascades (Guterl et al., 2012; Sommer et al., 2013b). As our experimental approach focused on the application of non-commercial enzymes, we have integrated an alternative ADH from Geobacillus stearothermophilus. Data characterizing this enzyme are presented in this study.

\section{Cloning}

The cloning procedures for plasmids containing PDC and YqjM followed literature protocols (Guterl et al., 2012; Sommer et al., 2013b). A codon-optimized variant of the ADH gene (ADH-HT, NCBI accession number: CAA81612.1) was synthesized by Life Technologies (Regensburg, Germany). The artificial gene was cloned into the Escherichia coli-compatible vector pET-22b (Merck, Darmstadt, Germany) with C-terminal His-Tag via NdeI and XhoI restriction sites.

\section{Enzyme Preparation}

Enzyme expression was performed using E. coli BL21 (DE3) or HMS173 (DE3) (Novagen, Nottingham, UK) as host strains. Cultivations were carried out in shake flask cultures or in a 10-L Biostat C plus bioreactor (Sartorius Stedim, Göttingen, Germany). Recombinant cells were initially cultivated at $37^{\circ} \mathrm{C}$ in TB medium supplemented with kanamycin $\left(30-50 \mu \mathrm{g} \mathrm{mL} \mathrm{m}^{-1}\right)$, unless otherwise stated. The cells were induced with $1 \mathrm{mM}$ isopropyl- $\beta$-D-thiogalactopyranoside (IPTG) at $\mathrm{OD}_{600} 0.5-0.8$. Cultures were subsequently harvested and frozen at $-20^{\circ} \mathrm{C}$ until

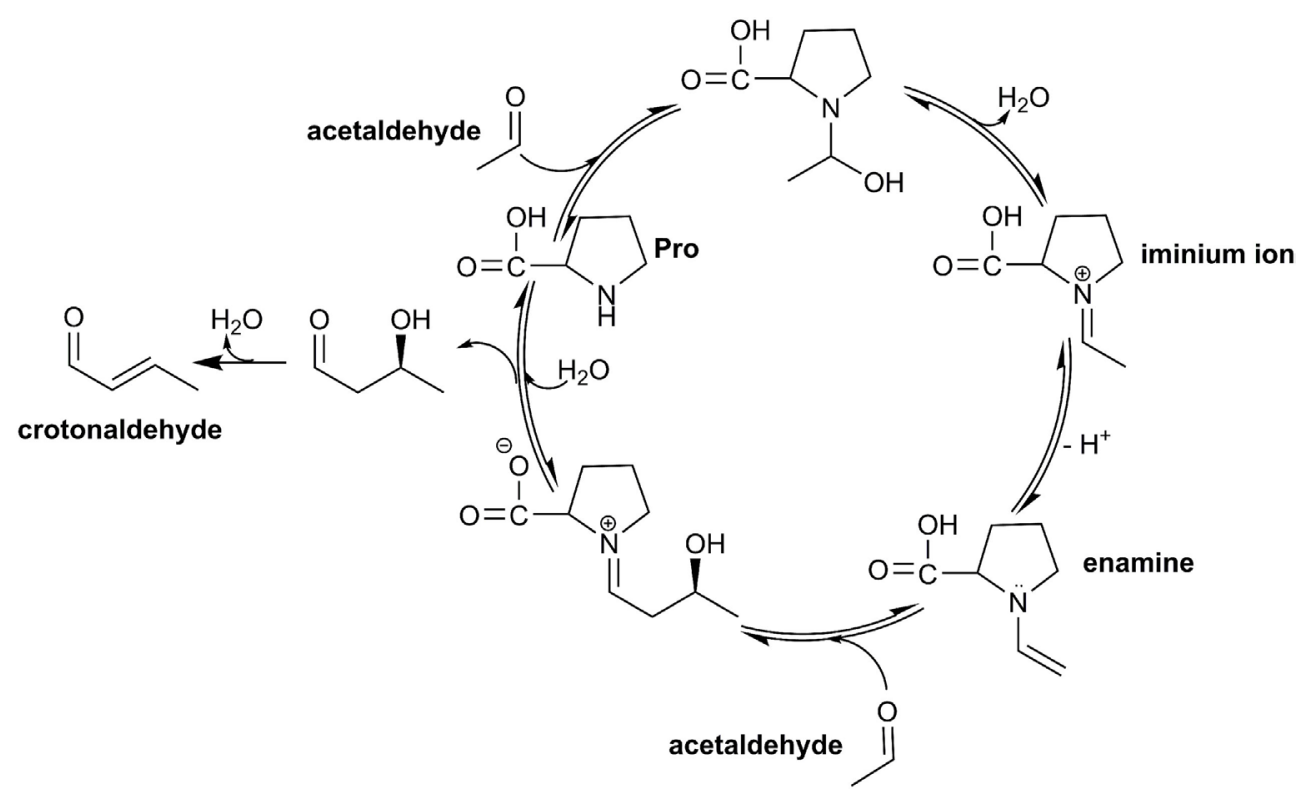

FIGURE 2 | Catalytic cycle of the enamine-aldol condensation of acetaldehyde, applying the catalyst proline. 
further use. PDC was expressed in Zyp-5052 (Studier, 2005), YqjM in TB medium. After induction with IPTG, growing temperatures were lowered at 30 or $25^{\circ} \mathrm{C}$. ADH was expressed in a fed-batch cultivation method at $37^{\circ} \mathrm{C}$ using $\mathrm{LB}$ as medium supplemented with $0.25 \mathrm{mM} \mathrm{ZnSO}_{4}$ and $100 \mu \mathrm{g} \mathrm{mL}^{-1}$ ampicillin. The cells were induced with $0.3 \mathrm{mM}$ IPTG at $\mathrm{OD}_{600}=5$ and further cultivated for $4 \mathrm{~h}$ before harvest and storage at $-20^{\circ} \mathrm{C}$.

Cell lysates were prepared with an Emulsiflex-B15 (Avestin, Mannheim, Germany). Cell debris and protein aggregates were separated from the soluble fraction by centrifugation $(21,000 \times \mathrm{g}$, $4^{\circ} \mathrm{C}, 20 \mathrm{~min}$ ). The enzymes were purified (50 $\mathrm{mM}$ HEPES buffer, $\mathrm{pH}$ 7) via immobilized metal affinity chromatography (IMAC) using a NGC FPLC-system (Bio-Rad, Munich, Germany) equipped with a HisTrap FF column (GE Healthcare, Freiburg, Germany). Purified enzyme solutions were desalted using a HiPrep 26/10 Desalting-column (Bio-Rad) in $50 \mathrm{mM} \mathrm{HEPES} \mathrm{pH}$ 7 plus $10 \%$ glycerol for subsequent storage at $-80^{\circ} \mathrm{C}$.

\section{Enzyme Assays Baseline Spectrophotometric ADH Characterization} The baseline characterization of $\mathrm{ADH}$ was conducted photometrically in 96-well microtiter plate format using a Varioskan photometer (Thermo Scientific, Braunschweig, Germany). Reactions using $\mathrm{NADH}$ as cofactor could be monitored at $340 \mathrm{~nm}$ (molar extinction coefficient $\mathrm{NADH}=6.22 \mathrm{~L} \mathrm{mmol}^{-1} \mathrm{~cm}^{-1}$ ). Activities were measured by following the $\mathrm{NADH}$-dependent reduction of aldehydes to the corresponding alcohols in $100 \mathrm{mM} \mathrm{HEPES} \mathrm{buffer}$ $(\mathrm{pH} 7)$ and $2.5 \mathrm{mM} \mathrm{MgSO}_{4}$ at $50^{\circ} \mathrm{C}$, unless otherwise stated.

Optimum temperature and $\mathrm{pH}$ were determined by monitoring reduction rates of $1 \mathrm{mM}$ acetaldehyde with $0.3 \mathrm{mM} \mathrm{NADH}$ at different temperatures $\left(30-70^{\circ} \mathrm{C}\right)$ and in different buffers (sodium phosphate $\mathrm{pH}$ 5.5-6.5, HEPES $\mathrm{pH}$ 6.5-7, and TRIS $\mathrm{pH}$ $7-8)$, respectively. Thermal stability was tested by measuring $\mathrm{ADH}$ activity after different incubation times $(0-24 \mathrm{~h})$ at 50 , 60 , and $70^{\circ} \mathrm{C}$. $\mathrm{ADH}$ kinetic parameters were determined with $0.3 \mathrm{mM} \mathrm{NADH}$ and varying concentrations of acetaldehyde (0.01-0.14 mM) or butyraldehyde (0.8-3 mM).

\section{Enzyme Assays for $n$-Butanol Cascade Design}

For the reaction cascade design, all enzyme activities (PDC, YqjM, and $\mathrm{ADH}$ ) were determined under comparable reaction conditions and analyzed using a Thermo Scientific Trace GC Ultra gas chromatograph with flame ionization detector (FID). Reaction mixtures were incubated in a $2-\mathrm{mL} \mathrm{GC}$-Vial at $50^{\circ} \mathrm{C}$ in a water bath for accurate temperature control, whereby the $\mathrm{pH}$ was adjusted to the corresponding temperature. The reaction was stopped at several time points with $7 \%$ trichloroacetic acid (TCA).

\section{PDC Assay}

The PDC was measured in an assay mixture containing $50 \mathrm{mM}$ HEPES buffer (pH 7), $20 \mathrm{mM}$ sodium pyruvate, $2.5 \mathrm{mM} \mathrm{MgSO}_{4}$, and $0.1 \mathrm{mM}$ thiamine pyrophosphate (TPP). The reaction products were analyzed by GC measurements.

\section{YqjM Assay}

2-Enoate reductase activity was measured in a coupled assay using a horse liver ADH (Evocatal GmbH, Monheim, Germany).
The reaction was carried out at $50^{\circ} \mathrm{C}(t=30 \mathrm{~min})$ in $50 \mathrm{mM}$ HEPES buffer ( $\mathrm{pH} 7$ ) containing $2.5 \mathrm{mM} \mathrm{MgSO}_{4}, 0.05 \mathrm{mM} \mathrm{FMN}$, and $20 \mathrm{mM}$ NADH as cofactors and $20 \mathrm{mM}$ crotonaldehyde. The reaction products were analyzed by GC measurements.

\section{ADH Assay}

Alcohol dehydrogenase activity was determined in $50 \mathrm{mM}$ HEPES buffer ( $\mathrm{pH} 7$ ) with $2.5 \mathrm{mM} \mathrm{MgSO}_{4}$ and $20 \mathrm{mM}$ butyraldehyde or acetaldehyde.

One unit of enzyme activity corresponds to the amount of enzyme, which reduces $1 \mu \mathrm{mol}$ substrate per minute.

\section{Enamine-Aldol Condensation}

Potential catalysts for the enamine-aldol condensation were screened with a dose of $20 \mathrm{mM}$ in $2 \mathrm{~mL}$ GC vials containing $20 \mathrm{mM}$ acetaldehyde and $50 \mathrm{mM}$ HEPES buffer ( $\mathrm{pH} \mathrm{7})$. The vials were incubated in a water bath at $50^{\circ} \mathrm{C}$ for up to $3 \mathrm{~h}$ and subsequently analyzed via GC. The reactions were stopped with 7\% TCA.

In particular, the proline reaction was thoroughly examined with respect to its temperature $\left(40-90^{\circ} \mathrm{C}\right), \mathrm{pH}(5.5-10)$, and concentration (1-500 $\mathrm{mM})$ dependency. The $\mathrm{pH}$ dependency was measured either in a $50 \mathrm{mM}$ MES ( $\mathrm{pH}$ 5.5-6.5), HEPES ( $\mathrm{pH}$ 7-8), TAPS ( $\mathrm{pH} 9$ ), or CAPS ( $\mathrm{pH} 10$ ) buffer system, respectively.

\section{Baseline Characterization and Optimization of the Reaction System}

Required enzyme quantities for the cell-free $n$-butanol production were calculated based on the previous reference measurements for individual unit activities: $\mathrm{PDC}=72.8 \pm 0.9 \mathrm{U} \mathrm{mL}^{-1}$ (toward pyruvate), YqjM $=1.1 \pm 0.1 \mathrm{U} \mathrm{mL}^{-1}$ (toward crotonaldehyde), $\mathrm{ADH}=4592 \pm 65.7 \mathrm{U} \mathrm{mL}^{-1}$ (toward acetaldehyde), and $183.1 \pm 3.7 \mathrm{U} \mathrm{mL}^{-1}$ (toward butyraldehyde). The proline dose was calculated based on previous control experiments carried out with different proline concentrations.

\section{Optimizing the Reaction System}

To determine the optimal biocatalyst composition, various reaction designs were examined. All reaction mixtures comprise $20 \mathrm{mM}$ pyruvate, $0.05 \mathrm{mM}$ FMN, $20 \mathrm{mM} \mathrm{NADH}, 2.5 \mathrm{mM} \mathrm{MgSO}_{4}$, and $0.1 \mathrm{mM}$ TPP in $50 \mathrm{mM}$ HEPES buffer ( $\mathrm{pH} 7)$. To determine the optimal enzyme activity ratios different reaction designs were examined: Reaction 1: $0.25 \mathrm{U} \mathrm{mL}^{-1} \mathrm{PDC}$, YqjM, $\mathrm{ADH}$, and $0.5 \mathrm{U} \mathrm{mL}^{-1}$ proline; Reaction 2: $0.5 \mathrm{U} \mathrm{mL}^{-1} \mathrm{PDC}$, proline, and $0.25 \mathrm{U} \mathrm{mL}^{-1}$ YqjM, ADH; Reaction 3: $0.5 \mathrm{U} \mathrm{mL}^{-1}$ PDC, YqjM, $\mathrm{ADH}$, and proline; Reaction 4: $0.5 \mathrm{U} \mathrm{mL}^{-1} \mathrm{PDC}$, YqjM, $\mathrm{ADH}$, and $0.25 \mathrm{U} \mathrm{mL}^{-1}$ proline. Reactions were carried out at $50^{\circ} \mathrm{C}$ without stirring over $10 \mathrm{~h}$.

Starting with pyruvate, the whole production cascade was eventually screened in triplicate in $2 \mathrm{~mL}$ GC vials. All required biocatalysts and their ligands are stated in Table 1 . The reaction mixture contained $20 \mathrm{mM}$ pyruvate, $319 \mathrm{mM}$ proline, $0.05 \mathrm{mM}$ FMN, $20 \mathrm{mM} \mathrm{NADH}, 2.5 \mathrm{mM} \mathrm{MgSO}_{4}$, and $0.1 \mathrm{mM}$ TPP in $50 \mathrm{mM}$ HEPES buffer ( $\mathrm{pH} 7$ ). The final acetaldehyde conversion rate was set to $0.25 \mathrm{U} \mathrm{mL}^{-1}$. To initiate the reaction, an enzyme mixture containing $0.5 \mathrm{U} \mathrm{mL}^{-1} \mathrm{PDC}, 0.5 \mathrm{U} \mathrm{mL}^{-1}$ YqjM, and $0.5 \mathrm{U} \mathrm{mL}^{-1} \mathrm{ADH}$ (toward butyraldehyde) was added to each vial. 
TABLE 1 | Required biocatalysts to generate $n$-butanol from pyruvate.

\begin{tabular}{lllll}
\hline$\#$ & Biocatalyst & EC \# & Substrate & Product \\
\hline 1 & $\begin{array}{l}\text { Pyruvate decarboxylase } \\
\text { (PDC) }\end{array}$ & 4.1 .1 .1 & Pyruvate & Acetaldehyde \\
2 & $\begin{array}{l}\text { Proline } \\
3\end{array}$ & - & Acetaldehyde & Crotonaldehyde \\
4 & Alcohol dehydrogenase (ADH) & 1.1 .1 .1 & Butyraldehyde & n-Butanol \\
\end{tabular}

Control reactions were performed without enzyme addition. The vials were placed in a water bath and incubated at $50^{\circ} \mathrm{C}$ without stirring. Samples were collected at constant $2 \mathrm{~h}$ time intervals over $10 \mathrm{~h}$. Reactions were stopped for GC analysis by addition of 7\% TCA. Samples for high-performance liquid chromatography (HPLC) analysis were pretreated by filtration $(10 \mathrm{kDa}$ MWCO Zentrifugal Filter, VWR, Darmstadt, Germany). Collected samples were subsequently analyzed via GC and HPLC to determine the product and intermediates.

\section{Analytical Methods}

Aldehydes and alcohols were separated and quantified by gas chromatography using Trace GC Ultra (Thermo Scientific, Braunschweig, Germany), equipped with Headspace Tri Plus autosampler, an agitator and FID. All compounds were separated via a Stabilwax column (length $30 \mathrm{~m}, 0.25 \mathrm{~mm}$ internal diameter, $0.25 \mu \mathrm{m}$ film thickness; Restek, Bad Homburg, Germany), with helium $\left(1.2 \mathrm{~mL} \mathrm{~min}^{-1}\right)$ as carrier gas. The oven temperature was programed to be held at $50^{\circ} \mathrm{C}$ for $2 \mathrm{~min}$, raised with a ramp of

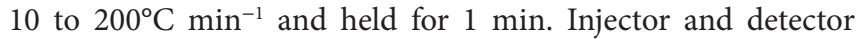
were kept at $200^{\circ} \mathrm{C}$. Samples were incubated prior to injection at $40^{\circ} \mathrm{C}$ for $15 \mathrm{~min}$. For the analysis, $700 \mu \mathrm{L}$ of the headspace were injected (headspace syringe $100^{\circ} \mathrm{C}$ ) in the split mode with a flow of $10 \mathrm{~mL} \mathrm{~min}{ }^{-1}$.

Pyruvate was separated and quantified via HPLC, using an Ultimate-3000 HPLC-system (Thermo Scientific, Braunschweig, Germany), equipped with an autosampler, a thermostatic column compartment, and a diode-array detector. The separation was achieved on a Metrosep Supp A16 column (25 mm, particle size $4.6 \mu \mathrm{m}$; Metrohm, Filderstadt, Germany) at $65^{\circ} \mathrm{C}$ by isocratic elution with $12 \mathrm{mM}$ ammonium bicarbonate ( $\mathrm{pH} \mathrm{10),} \mathrm{followed} \mathrm{by}$ a washing step with $30 \mathrm{mM}$ sodium carbonate ( $\mathrm{pH}$ 10.4). Mobile phase flow was adjusted to $0.2 \mathrm{~mL} \mathrm{~min}^{-1}$.

\section{RESULTS}

\section{Evaluation of Potential Catalysts for the Enamine-Aldol Condensation}

Potential catalysts for the desired enamine condensation were selected and tested with acetaldehyde in $50 \mathrm{mM}$ HEPES buffer $(\mathrm{pH} 7)$ at $50^{\circ} \mathrm{C}$ for maximal $3 \mathrm{~h}$. The selected panel of natural organocatalysts comprises the amino acids arginine and proline as well as the polyamine spermidine. The amino acid alanine served as a negative control. While proline (List, 2002) was reported to harbor the desired nucleophilic reactivity, arginine was selected due to the secondary amine function that comprises its side chain. As spermidine also possesses secondary amines, it also represents potential catalytic candidate (Theruvathu et al., 2005).

Proline displayed the best conversion rate of acetaldehyde to crotonaldehyde with $5.7 \pm 0.2 \times 10^{-3} \mu \mathrm{mol} \mathrm{min}^{-1} \mathrm{~mL}^{-1}$ (Figure 3). With respect to the proline reaction rate, arginine and the polyamine spermidine accomplished $46 \%$ of the reference value. As expected, the negative control alanine showed only $4 \%$ of the proline activity (Table 2 ).

\section{Optimizing Reaction Conditions}

To establish the new $n$-butanol cascade proline was selected and further examined regarding temperature, $\mathrm{pH}$, and concentration. Thereby, our standard reaction conditions ( $20 \mathrm{mM}$ proline, $50 \mathrm{mM}$ HEPES, $\mathrm{pH} 7$ at $50^{\circ} \mathrm{C}$ ) were adapted to the corresponding experiments.

The operational temperature dependency was determined by incubating the proline reaction mix between 40 and $90^{\circ} \mathrm{C}$. The formation of crotonaldehyde was subsequently monitored via GC-FID. As illustrated in Figure 4A, the proline activity was simultaneously rising with the temperature and could be increased tenfold from 50 to $90^{\circ} \mathrm{C}$.

Determination of $\mathrm{pH}$ effects on the proline reactivity were studied at $50^{\circ} \mathrm{C}$. The proline activity over a broad $\mathrm{pH}$ range was evaluated with each $50 \mathrm{mM}$ MES ( $\mathrm{pH}$ 5.5-6.5), HEPES ( $\mathrm{pH}$ 7-8), TAPS ( $\mathrm{pH} 9$ ), and CAPS ( $\mathrm{pH} 10$ ) buffer, respectively. We could measure a significant increase in activity with increasing $\mathrm{pH}$ (Figure 4B). Notably, the proline activity at $\mathrm{pH} 10$ was over 100 -fold higher than at neutral $\mathrm{pH}$.

As the organocatalyst concentration is a key process parameter, we have determined the aldol condensation in the presence of increasing proline concentrations (Figure 4C). The highest detectable proline activity was $494.6 \pm 4.6 \times 10^{-3} \mu \mathrm{mol} \mathrm{min}^{-1} \mathrm{~mL}^{-1}$ at $500 \mathrm{mM}$. With the provided data, proline could be set to specific conversion rates to achieve an optimal $n$-butanol production.

Although the proline-catalyzed aldol condensation favors higher $\mathrm{pH}$ and temperature values, the overall reaction conditions were set to $50^{\circ} \mathrm{C}$ and neutral $\mathrm{pH}$ with respect to the enzymes characteristics of $\mathrm{ADH}, \mathrm{PDC}$, and YqjM. While $\mathrm{ADH}$ accepted higher temperatures over $60^{\circ} \mathrm{C}$ (Table 3), PDC and YqjM preferred temperatures in the range of $50^{\circ} \mathrm{C}$ or less. All three enzymes additionally operated optimal at neutral or slightly acidic conditions (Gocke et al., 2007; Guterl et al., 2012; Sommer et al., 2013b).

Considering this pathway composition and the upstream glycolytic reaction module (Guterl et al., 2012), the chosen reaction parameters represent a feasible compromise that maintains activity for all required catalytic components albeit not operating at their individual optimum.

\section{In Vitro $n$-Butanol Synthesis}

The consolidated conversion of pyruvate to $n$-butanol was carried out at $50^{\circ} \mathrm{C}$ for $10 \mathrm{~h}$ and neutral $\mathrm{pH}$ conditions. Proline was applied as an organocatalyst for the desired enamine-aldol condensation due to its superior reaction rate compared with other evaluated amines. All reaction intermediates and products were quantified with authentic standards using established GC and HPLC protocols. 


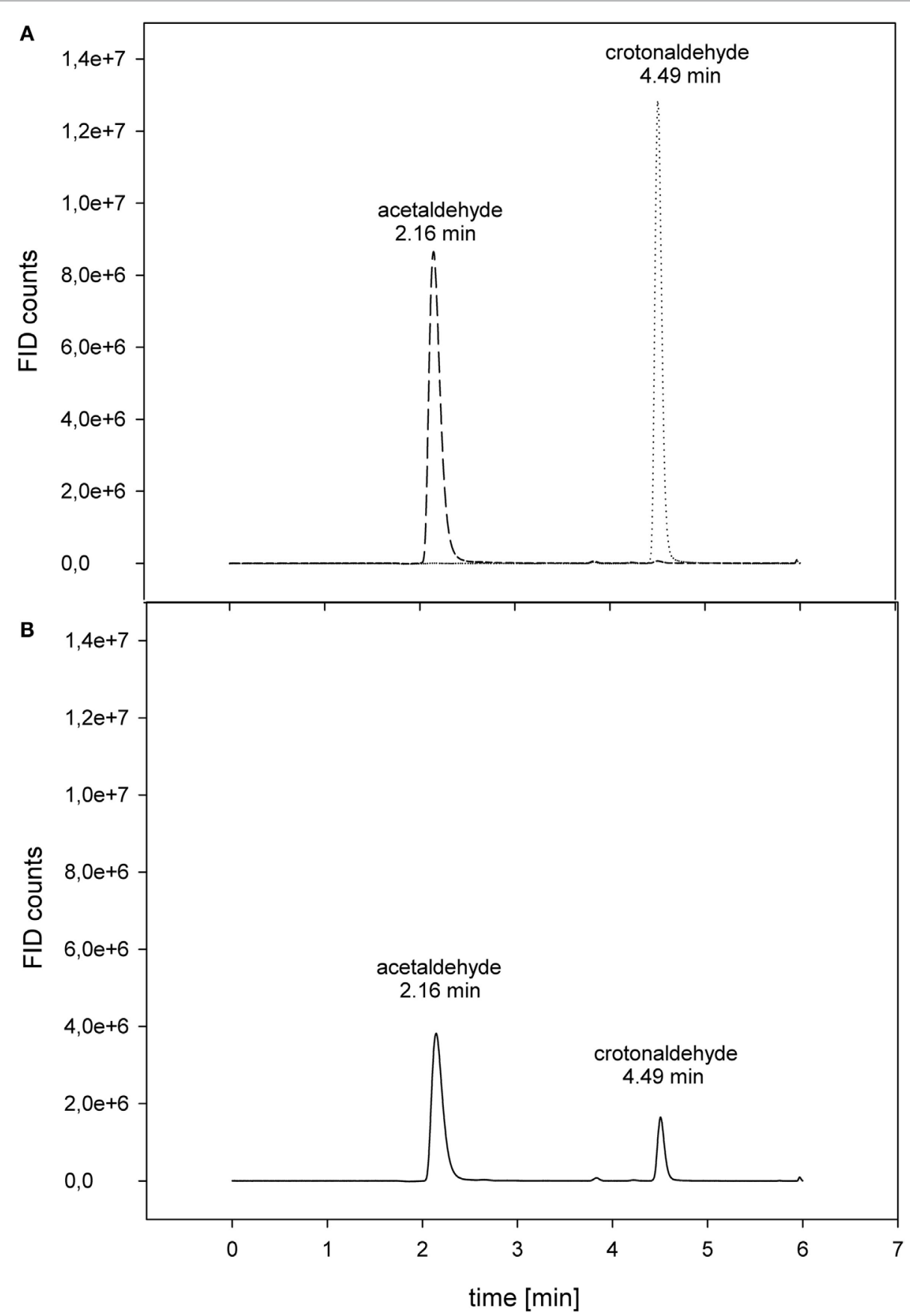

FIGURE 3 | Conversion of acetaldehyde to crotonaldehyde via proline. (A) Separate control measurements: - - $20 \mathrm{mM}$ acetaldehyde; ...... 20 mM crotonaldehyde. (B) Crotonaldehyde biosynthesis. The reaction (-) was carried out at $50^{\circ} \mathrm{C}$ in $50 \mathrm{mM} \mathrm{HEPES} \mathrm{buffer} \mathrm{(pH} 7$ ) with $20 \mathrm{mM}$ acetaldehyde as substrate.

Initially, various reaction designs were examined in single tests to identify the optimal organo-/biocatalyst composition. Therefore, different enzyme and proline activities were evaluated and compared, as illustrated in Figure S1 in Supplementary Material. The GC data indicated that our designed in vitro biocatalytic reaction cascade allows the direct conversion of pyruvate to $n$-butanol. The best result of $2 \mathrm{mM} n$-butanol was obtained by the combination of $0.5 \mathrm{U} \mathrm{mL}^{-1}$ PDC, YqjM, ADH, and $0.25 \mathrm{U} \mathrm{mL}^{-1}$ proline.

Subsequently, the reaction cascade was then tested in triplicate, whereby each independent experiment was triggered by addition of the enzyme mix leading to the formation of $2.0 \pm 0.0 \mathrm{mM}$ $n$-butanol (Figure 5). The $n$-butanol production rate remained constant during the first $4 \mathrm{~h}$ and achieved a production rate of 
nearly $0.01 \mu \mathrm{mol} \mathrm{min} \mathrm{mL}^{-1} \mathrm{~mL}^{-1}$, which is comparable to a different cell-free approach reported by the Ohtake group (Krutsakorn et al., 2013). After $4 \mathrm{~h}$, the $n$-butanol production rate decreased and finally sized at $8 \mathrm{~h}$. En route to $n$-butanol formation we could detect acetaldehyde, crotonaldehyde, and butyraldehyde as intermediates, which were almost completely consumed after $8 \mathrm{~h}$.

In addition to $n$-butanol, we could also detect significant ethanol formation $(c=4.9 \pm 0.0 \mathrm{mM})$ as a reaction byproduct. As shown in Table 3, ADH showed a strong substrate preference for acetaldehyde over butyraldehyde, which lead to an unfavorable substrate flux. Hence, the $\mathrm{ADH}$ reaction limited the acetaldehyde and the subsequent intermediate pools.

\section{DISCUSSION}

The focus of this study was the design of an in vitro thermostable, biocatalytic reaction cascade that provides for the conversion of pyruvate to $n$-butanol with minimal enzyme activities and in the absence of any CoA-dependent intermediates. What is more, the reaction cascade should be modularly compatible with our previously reported in vitro production toolbox for the production of industrial solvents (Guterl et al., 2012).

This toolbox utilizes an artificial glycolytic reaction cascade. While the in vitro production of ethanol and isobutanol have been successfully reported previously (Guterl et al., 2012), designing a

TABLE 2 | Conversion rates for the transformation of acetaldehyde to crotonaldehyde.

\begin{tabular}{ll}
\hline Organocatalyst & $\boldsymbol{v}\left(\boldsymbol{\mu} \mathbf{m o l ~} \mathbf{~ m i n}^{-1} \mathbf{~ m L}^{-1}\right)$ \\
\hline Proline & $5.7 \pm 0.2 \times 10^{-3}$ \\
Arginine & $2.6 \pm 0.1 \times 10^{-3}$ \\
Spermidine & $2.6 \pm 0.0 \times 10^{-3}$ \\
Alanine & $0.2 \pm 0.0 \times 10^{-3}$
\end{tabular}

All organocatalysts were tested at a concentration of $20 \mathrm{mM}$ at $50^{\circ} \mathrm{C}$ in $50 \mathrm{mM}$ HEPES buffer ( $\mathrm{PH} 7$ ), containing $20 \mathrm{mM}$ acetaldehyde. cell-free enzyme cascade for $n$-butanol was challenging particularly with respect to harmonizing enzyme activities and cofactor concentrations.

To circumvent these limitations and reduce required enzyme activities, we designed a new biocatalytic $n$-butanol pathway. Our consolidated $n$-butanol production pathway operates with only three enzyme activities, NADH as the sole redox mediator and an amino acid catalyzed enamine-aldol condensation as the essential biocatalytic component that enables a $\mathrm{C}-\mathrm{C}$ bond formation leading to the required $\mathrm{C} 4$ building block.

In the first proof-of-concept experiment, we could successfully produce $2 \mathrm{mM} n$-butanol, which corresponds to $148 \mathrm{mg} \mathrm{L}^{-1}$. Even with this prototypic approach, we could already achieve a 60 -fold increase of the $n$-butanol yield compared with a recently reported cell-based route utilizing an engineered Saccharomyces cerevisiae (2.5 $\mathrm{mg} \mathrm{L}^{-1}$ ) system (Steen et al., 2008). Nevertheless, recent studies present much higher $n$-butanol titer for cell-based approaches. The native $n$-butanol producer $C$. acetobutylicum achieved $\sim 12 \mathrm{~g} \mathrm{~L}^{-1}$ (Harris et al., 2001; Lee et al., 2008), while different mutants reached $17.6 \mathrm{~g} \mathrm{~L}^{-1}$ (Jang et al., 2013) and $18.6 \mathrm{~g} \mathrm{~L}^{-1}$, respectively (Formanek et al., 1997). Engineered E. coli strains

\section{TABLE 3 | Geobacillus stearothermophilus ADH characteristics.}

\begin{tabular}{ll}
\hline Parameter & Value \\
\hline Optimum temperature & $60^{\circ} \mathrm{C}$ \\
Thermal stability $\left(50^{\circ} \mathrm{C}\right)$ & $t / 2 \geq 24 \mathrm{~h}$ \\
Thermal stability $\left(60^{\circ} \mathrm{C}\right)$ & $t / 2=12 \mathrm{~h}$ \\
Thermal stability $\left(70^{\circ} \mathrm{C}\right)$ & $t / 2=2 \mathrm{~h}$ \\
Optimum pH & 6 \\
$\mathrm{pH}$ range & $5.5-8$ \\
$K_{\mathrm{m}}{ }^{\mathrm{a}}$ acetaldehyde/butyraldehyde & $0.065 \pm 0.005 \mathrm{mM} / 1.43 \pm 0.16 \mathrm{mM}$ \\
$K_{\text {cat }}$ acetaldehyde/butyraldehyde & $141.44 \pm 14.52 \mathrm{~s}^{-1} / 49.16 \pm 3.8 \mathrm{~s}^{-1}$ \\
$K_{\text {cat }} / K_{\mathrm{m}}$ acetaldehyde/butyraldehyde & $2184 \pm 393 \mathrm{mM}^{-1} \mathrm{~s}^{-1} / 34 \pm 7 \mathrm{mM}^{-1} \mathrm{~s}^{-1}$ \\
\hline
\end{tabular}

${ }^{a}$ The kinetic constants were measured with appropriate concentrations of $\mathrm{NADH}$ and various concentrations of the corresponding substrate (acetaldehyde: 0.01-0.14 mM/ butyraldehyde $0.8-3 \mathrm{mM}$ ) in $100 \mathrm{mM} \mathrm{HEPES} \mathrm{pH} 7$ at $50^{\circ} \mathrm{C}$.
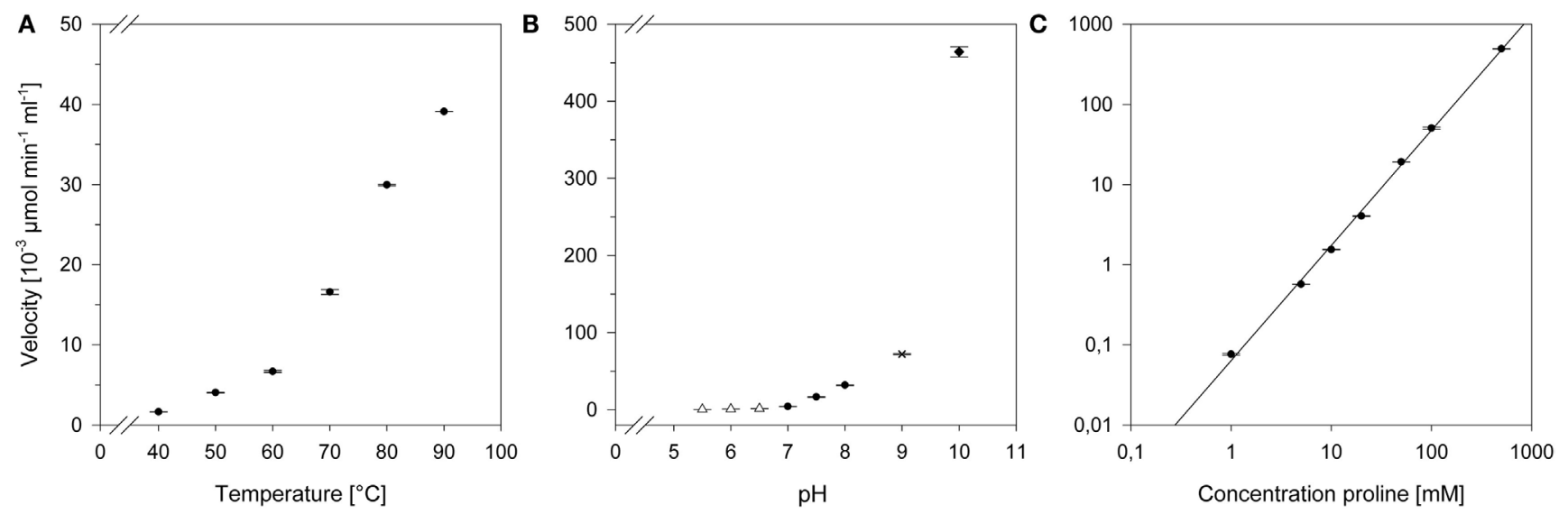

FIGURE 4 | Effects of different conditions on the proline activity. (A) Temperature profile: the reactions were carried out at described conditions in a range from 40 to $90^{\circ} \mathrm{C}$. (B) $\mathrm{pH}$ profile: the reactions were carried out at described conditions with following buffers: $\Delta, 50 \mathrm{mM} \mathrm{MES} \mathrm{buffer,} \mathrm{pH} \mathrm{5.5-6.5;}, 50 \mathrm{mM} \mathrm{HEPES}$, $\mathrm{pH} 7-8 ; \times, 50 \mathrm{mM}$ Taps, $\mathrm{pH}$ 9;, $50 \mathrm{mM}$ CAPS, $\mathrm{pH}$ 10. (C) Concentration-dependent activity: aldol condensation was determined in presence of various proline concentrations ranging from 1 to $500 \mathrm{mM}$. The scale is logarithmic. 


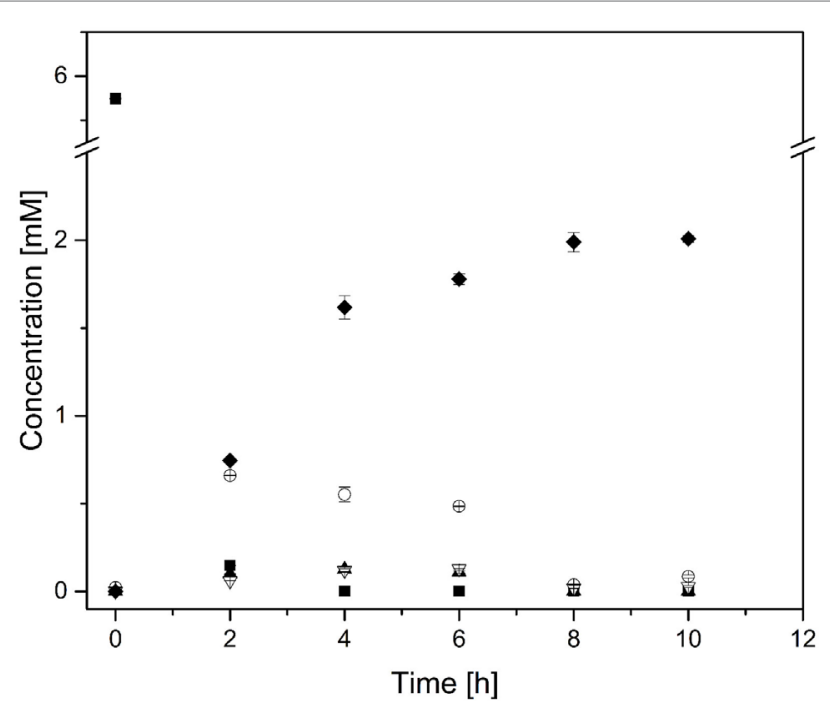

FIGURE $5 \mid \boldsymbol{n}$-Butanol biosynthesis via the proline-catalyzed enamine-aldol condensation. $n$-Butanol production time profile. The reaction was carried out in $2 \mathrm{~mL}$ GC vials, without stirring at $50^{\circ} \mathrm{C}$ and neutral $\mathrm{pH}$. —, Pyruvate; $\bigcirc$, Acetaldehyde; $\boldsymbol{\Delta}$, Crotonaldehyde; $\nabla$, Butyraldehyde; , $n$-Butanol. Note that the concentration of pyruvate and acetaldehyde was halved due to a better comparison with $n$-butanol concentration $(2 \mathrm{~mol}$ pyruvate is converted to $1 \mathrm{~mol} n$-butanol).

produced $n$-butanol with a broad product titer spectrum, ranging from $~ 500 \mathrm{mg} \mathrm{L}^{-1}$ (Atsumi et al., 2008; Nielsen et al., 2009) to $30 \mathrm{~g} \mathrm{~L}^{-1}$ (Shen et al., 2011). Compared with the cell-based achieved titer, our current in vitro system requires further improvements.

Using the first principles approach for optimization of our cell-free $n$-butanol cascade, we compared the kinetic properties of the required enzyme activities. With the exception of YqjM, kinetic properties for all other enzyme activities could be extracted from reference data. The exact kinetic properties of YqjM under aerobe conditions could not be determined due to side-reactions with molecular oxygen, which led to a nonproductive reduction of the NADH pool (Sommer et al., 2013b). Therefore, experimental optimization procedures were based on $\mathrm{ADH}$ and PDC kinetic data.

The ADH $k_{\text {cat }}$ for acetaldehyde $\left(141.44 \mathrm{~s}^{-1}\right)$ was 10 -fold higher than for butyraldehyde $\left(49.16 \mathrm{~s}^{-1}\right)$ (Table 3$)$ and the PDC $k_{\text {cat }}$ for pyruvate $\left(113 \mathrm{~s}^{-1}\right)$ was in a similar order of magnitude to the corresponding $\mathrm{ADH}$ value for butyraldehyde (Chang et al., 2000). Considering the proline reaction rate at neutral $\mathrm{pH}$ and $50^{\circ} \mathrm{C}$, we therefore restricted the enzyme activities initially to half of the proline reaction rate. The activities were therefore set to $0.25 \mathrm{U} \mathrm{mL}^{-1}$, while proline was set to $0.5 \mathrm{U} \mathrm{mL}^{-1}$ (Reaction 1). However, this approach led only to $0.8 \mathrm{mM} n$-butanol (Figure S1 in Supplementary Material). Finally, the reaction with the opposite combination of the enzyme activities $\left(0.5 \mathrm{U} \mathrm{mL}^{-1}\right)$ and proline reaction rate $\left(0.25 \mathrm{U} \mathrm{mL}^{-1}\right)$ led to the best result of $2 \mathrm{mM}$ n-butanol.

The collective data in this study indicate two factors currently limiting $n$-butanol formation. A primary engineering target would be substrate preference of the $\mathrm{ADH}$ activity, as the kinetic properties showed a strong preference of acetaldehyde instead of butyraldehyde as a substrate, which results in undesired ethanol (4.9 $\mathrm{mM}$ ) production, thereby reducing the $n$-butanol yield. However, acetaldehyde is an essential upstream intermediate of the $n$-butanol pathway and cannot be substituted. Therefore, a new or engineered $\mathrm{ADH}$ activity that favors higher aldehydes would be advantageous. As there are currently no $\mathrm{ADH}$ variants with increased butyraldehyde selectivity available, an extensive mutagenesis project possibly in combination with high content activity screening is required to generate the required enzyme activity.

Further pathway improvement could be achieved by replacing proline with a synthetic analog that provides even higher reaction rates at neutral $\mathrm{pH}$ and lower temperatures. However, this approach requires extended chemical synthesis and kinetic studies that are beyond the scope of study. Similarly, the issue of the long-term stability of the redox cofactor $\mathrm{NADH}$ still remains, which also could be solved by substituting NADH with a synthetic analogous of higher reactivity and stability (Kaufman, 1998; Ansell and Lowe, 1999; Oohora and Hayashi, 2014). The addition of alternative catalysts to enhance the reaction rate is therefore principally possible but has to be harmonized with the remaining enzyme activities of our designed reaction cascade.

Nonetheless, our cell-free $n$-butanol production route compares well with previously reported in vitro $n$-butanol technologies. For instance, the $n$-butanol production route reported by the Ohtake group applied almost the entire clostridial biosynthesis pathway. This pathway was reconstructed in vitro with a final $n$-butanol titer of $260 \mathrm{mg} \mathrm{L}^{-1}$ (Krutsakorn et al., 2013). To convert pyruvate to $n$-butanol, this approach required seven enzymes and two metabolic cofactors (NADH and CoA).

In contrast, our condensed in vitro concept requires only three enzymes, NADH as single cofactor and achieved $148 \mathrm{mg} \mathrm{L}^{-1}$ with a similar initial production rate of $0.01 \mu \mathrm{mol} \mathrm{min}{ }^{-1} \mathrm{~mL}^{-1}$. Additionally, the combined biocatalytic $n$-butanol production pathway eliminates the need for any intermediate titration. Moreover, this pathway can be excellently integrated into our previously reported enzyme toolbox for in vitro solvent production (Guterl et al., 2012). A complete integration of the current reaction cascade would provide for direct conversion of glucose to $n$-butanol.

In summary, to complete our modular in vitro system to produce industrial solvents, we could successfully show the production of $n$-butanol via a new condensed pathway. Although the aldol condensation step restricted the overall reaction due to the limited reaction rate, we could compete with alternative cell-free $n$-butanol production concepts. The presented in vitro $n$-butanol production system demonstrates the capacity modern synthetic biotechnology methodologies and the synergies of chemoenzymatic technologies.

\section{AUTHOR CONTRIBUTIONS}

SR and TB conceived the study. SR, TB, DG, MH, FB, and VS planned the experimental work. SR, DG, MH, BS, FS, and JC selected, prepared, and analyzed enzyme reactions described in this study. All authors contributed to data interpretation, 
drafting, and refining the manuscript versions. SR, TB, DG, MH, and VS finalized the publishable manuscript. All authors agree to be accountable for the integrity of work presented in the current manuscript.

\section{ACKNOWLEDGMENTS}

$\mathrm{SR}, \mathrm{FB}$, and TB are associated with BB-SI GmbH. VS is associated with CASCAT GmbH. Both BB-SI GmbH and CASCAT GmbH are commercial entities that act synergistically in the development and commercialization of designed in vitro enzyme cascades for renewable production of sustainable platform chemicals. The data

\section{REFERENCES}

Ansell, R. J., and Lowe, C. R. (1999). Artificial redox coenzymes biomimetic analogues of NAD(+). Appl. Microbiol. Biotechnol. 51, 703-710. doi:10.1007/ s002530051455

Atsumi, S., Cann, A. F., Connor, M. R., Shen, C. R., Smith, K. M., Brynildsen, M. P., et al. (2008). Metabolic engineering of Escherichia coli for 1-butanol production. Metab. Eng. 10, 305-311. doi:10.1016/j.ymben.2007.08.003

Bar-Even, A., Flamholz, A., Noor, E., and Milo, R. (2012). Rethinking glycolysis: on the biochemical logic of metabolic pathways. Nat. Chem. Biol. 8, 509-517. doi:10.1038/nchembio.971

Chang, A. K., Nixon, P. F., and Duggleby, R. G. (2000). Effects of deletions at the carboxyl terminus of Zymomonas mobilis pyruvate decarboxylase on the kinetic properties and substrate specificity. Biochemistry 39, 9430-9437. doi:10.1021/ bi0002683

Dürre, P. (2007). Biobutanol: an attractive biofuel. Biotechnol. J. 2, 1525-1534. doi:10.1002/biot.200700168

Dusseaux, S., Croux, C., Soucaille, P., and Meynial-Salles, I. (2013). Metabolic engineering of Clostridium acetobutylicum ATCC 824 for the high-yield production of a biofuel composed of an isopropanol/butanol/ethanol mixture. Metab. Eng. 18, 1-8. doi:10.1016/j.ymben.2013.03.003

Engel, C. K., Mathieu, M., Zeelen, J. P., Hiltunen, J. K., and Wierenga, R. K. (1996). Crystal structure of enoyl-coenzyme A (CoA) hydratase at 2.5 angstroms resolution: a spiral fold defines the CoA-binding pocket. EMBO J. 15, 5135-5145.

Formanek, J., Mackie, R., and Blaschek, H. P. (1997). Enhanced butanol production by Clostridium beijerinckii BA101 grown in semidefined P2 medium containing 6 percent maltodextrin or glucose. Appl. Environ. Microbiol. 63, 2306-2310.

Gao, C., Qiu, J., Li, J., Ma, C., Tang, H., and Xu, P. (2009). Enantioselective oxidation of racemic lactic acid to D-lactic acid and pyruvic acid by Pseudomonas stutzeri SDM. Bioresour. Technol. 100, 1878-1880. doi:10.1016/j.biortech.2008. 09.053

Gocke, D., Nguyen, C. L., Pohl, M., Stillger, T., Walter, L., and Müller, M. (2007). Branched-chain keto acid decarboxylase from Lactococcus lactis (KdcA), a valuable thiamine diphosphate-dependent enzyme for asymmetric $\mathrm{C}-\mathrm{C}$ bond formation. Adv. Synth. Catal. 349, 1425-1435. doi:10.1002/adsc.200700057

Guterl, J. K., Garbe, D., Carsten, J., Steffler, F., Sommer, B., Reisse, S., et al. (2012). Cell-free metabolic engineering: production of chemicals by minimized reaction cascades. ChemSusChem 5, 2165-2172. doi:10.1002/cssc.201200365

Harris, L. M., Blank, L., Desai, R. P., Welker, N. E., and Papoutsakis, E. T. (2001). Fermentation characterization and flux analysis of recombinant strains of Clostridium acetobutylicum with an inactivated solR gene. J. Ind. Microbiol. Biotechnol. 27, 322-328. doi:10.1038/sj/jim/7000191

Inui, M., Suda, M., Kimura, S., Yasuda, K., Suzuki, H., Toda, H., et al. (2008). Expression of Clostridium acetobutylicum butanol synthetic genes in Escherichia coli. Appl. Microbiol. Biotechnol. 77, 1305-1316. doi:10.1007/s00253-0071257-5

Jang, Y.-S., Malaviya, A., and Lee, S. Y. (2013). Acetone-butanol-ethanol production with high productivity using Clostridium acetobutylicum BKM19. Biotechnol. Bioeng. 110, 1646-1653. doi:10.1002/bit.24843 presented in this manuscript represent the basis for the associated European Patent application EP 15003214.

\section{FUNDING}

This work was supported by the German Federal Ministry of Education and Research (BMBF) under grant number 0315485B.

\section{SUPPLEMENTARY MATERIAL}

The Supplementary Material for this article can be found online at http://journal.frontiersin.org/article/10.3389/fbioe.2016.00074

Kaufman, R. A. (1998). Use of NADPH and NADH Analogs in the Measurement of Enzyme Activities and Metabolites. US5801006 A. Washington, DC: U.S. Patent and Trademark Office.

Krutsakorn, B., Honda, K., Ye, X., Imagawa, T., Bei, X., Okano, K., et al. (2013). In vitro production of n-butanol from glucose. Metab. Eng. 20, 84-91. doi:10.1016/j.ymben.2013.09.006

Lee, S. Y., Park, J. H., Jang, S. H., Nielsen, L. K., Kim, J., and Jung, K. S. (2008). Fermentative butanol production by Clostridia. Biotechnol. Bioeng. 101, 209-228. doi:10.1002/bit.22003

Li, H., Cann, A. F., and Liao, J. C. (2010). Biofuels: biomolecular engineering fundamentals and advances. Annu. Rev. Chem. Biomol. Eng. 1, 19-36. doi:10.1146/ annurev-chembioeng-073009-100938

Lin, Y. L., and Blaschek, H. P. (1983). Butanol production by a butanol-tolerant strain of Clostridium acetobutylicum in extruded corn broth. Appl. Environ. Microbiol. 45, 966-973.

List, B. (2002). Proline-catalyzed asymmetric reactions. Tetrahedron 58, 5573-5590. doi:10.1016/S0040-4020(02)00516-1

Nielsen, D. R., Leonard, E., Yoon, S. H., Tseng, H. C., Yuan, C., and Prather, K. L. (2009). Engineering alternative butanol production platforms in heterologous bacteria. Metab. Eng. 11, 262-273. doi:10.1016/j.ymben.2009.05.003

Oohora, K., and Hayashi, T. (2014). Incorporation of modified and artificial cofactors into naturally occurring protein scaffolds. Methods Mol. Biol. 1216, 251-263. doi:10.1007/978-1-4939-1486-9_13

Reisse, S., Garbe, D., and Bruck, T. (2014). Meiothermus ruber thiolase - a new process stable enzyme for improved butanol synthesis. Biochimie 103, 16-22. doi:10.1016/j.biochi.2014.03.013

Shen, C. R., Lan, E. I., Dekishima, Y., Baez, A., Cho, K. M., and Liao, J. C. (2011). Driving forces enable high-titer anaerobic 1-butanol synthesis in Escherichia coli. Appl. Environ. Microbiol. 77, 2905-2915. doi:10.1128/AEM.03034-10

Sommer, B., Garbe, D., Schrepfer, P., and Bruck, T. (2013a). Characterization of a highly thermostable beta-hydroxybutyryl CoA dehydrogenase from Clostridium acetobutylicum ATCC 824. J. Mol. Catalysis B Enzymatic 98, 138-144. doi:10.1016/j.molcatb.2013.10.014

Sommer, B., Haack, M., Garbe, D., and Brück, T. (2013b). Catalytic modules in non-natural butanol biosynthesis: conversion of the key intermediate crotylalcohol to N-butanol via a designed enzyme cascade. JSM Biotechnol. Biomed. Eng. 1, 1-7.

Steen, E. J., Chan, R., Prasad, N., Myers, S., Petzold, C. J., Redding, A., et al. (2008). Metabolic engineering of Saccharomyces cerevisiae for the production of n-butanol. Microb. Cell Fact. 7, 36. doi:10.1186/1475-2859-7-36

Studier, F. W. (2005). Protein production by auto-induction in high density shaking cultures. Protein Expr. Purif. 41, 207-234. doi:10.1016/j.pep.2005.01.016

Theruvathu, J. A., Jaruga, P., Nath, R. G., Dizdaroglu, M., and Brooks, P. J. (2005). Polyamines stimulate the formation of mutagenic 1,N2-propanodeoxyguanosine adducts from acetaldehyde. Nucleic Acids Res. 33, 3513-3520. doi:10.1093/nar/ gki661

Vollherbst-Schneck, K., Sands, J. A., and Montenecourt, B. S. (1984). Effect of butanol on lipid composition and fluidity of Clostridium acetobutylicum ATCC 824. Appl. Environ. Microbiol. 47, 193-194.

Xu, P., Qiu, J., Gao, C., and Ma, C. (2008). Biotechnological routes to pyruvate production. J. Biosci. Bioeng. 105, 169-175. doi:10.1263/jbb.105.169 
Conflict of Interest Statement: The authors declare that the research was conducted in the absence of any commercial or financial relationships that could be construed as a potential conflict of interest.

Copyright (C) 2016 Reiße, Haack, Garbe, Sommer, Steffler, Carsten, Bohnen, Sieber and Brück. This is an open-access article distributed under the terms of the Creative Commons Attribution License (CC BY). The use, distribution or reproduction in other forums is permitted, provided the original author(s) or licensor are credited and that the original publication in this journal is cited, in accordance with accepted academic practice. No use, distribution or reproduction is permitted which does not comply with these terms. 